\title{
IMPLEMENTASI KURIKULUM 2013 DALAM PEMBELAJARAN SMA
}

\author{
Julfahnur ${ }^{1)}$, Mustika Ratu M. ${ }^{2)}$, St. Diana ${ }^{3)}$, Idham Khalik ${ }^{4)}$ \\ ${ }^{1,2,3,4)}$ Program Studi Pendidikan Bahasa dan Sastra Indonesia \\ Fakultas Sastra, Universitas Muslim Indonesia \\ Email: julfahnurnur@gmail.com
}

\begin{abstract}
Abstrak: Kurikulum 2013 merupakan pengembangan atas kurikulum sebelumnya yaitu Kurikulum Tingkat Satuan Pendidikan (KTSP). Penerapan kurikulum 2013 di sekolah diharapkan lebih dapat memaksimalkan kemampuan dan mencoba menekan kelemahan bagi diri sendiri maupun lembaganya, sehingga dapat mengoptimalkan pemanfaatan sumber daya yang tersedia. Dalam melaksanakan program kurikulum 2013 yang lebih memfokuskan pada semua mata pelajaran yang harus didukung oleh semua kompetensi baik dalam sikap, keterampilan, dan pengetahuan. Implementasi kurikulum 2013 sangat menonjolkan pendekatan saintifik dengan pembelajaran yang hanya terpusat pada siswa. Pendekatan Saintifik adalah proses pembelajaran yang di rancang sedemikian rupa agar peserta didik secara aktif mengonstruk konsep, hukum dan prinsip melalui tahapan mengamati (untuk mengidentifikasi atau menemukan masalah, merumuskan masalah, mengajukan hipotesis, mengumpulkan data dengan berbagai teknik, menganalisis data, menarik kesimpulan, dan mengkomunikasikan konsep, hukum maupun prinsip yang ditemukan). Pendekatan ini juga dimaksudkan memberikan pemahaman kepada peserta didik dalam mengenal dan memahami berbagai materi menggunakan pendekatan ilmiah, bahwa informasi dapat diperoleh dari mana saja tidak harus bergantung pada informasi dari guru. Pada tahun 2013, Pemerintah telah menetapkan beberapa sekolah untuk menggunakan kurikulum 2013 dan mengimplementasikan dalam proses pembelajaran sesuai dengan standar proses yang berlaku, menjadikan konsep kurikulum dimaksudkan untuk dapat mengarahkan pendidikan menuju arah dan tujuan kegiatan pembelajaran secara keseluruhan.
\end{abstract}

Kata kunci: implementasi, kurikulum 2013, SMA

\section{PENDAHULUAN}

Kurikulum 2013 adalah kurikulum berbasis kompetensi, pengembangan kurikulum 2013 diarahkan pada pencapaian kompetensi yang dirumuskan dalam Standar Kompetensi Lulusan (SKL). Penyususnan kurikulum 2013 dimulai dengan menetapkan standar kompetensi lulusan berdasarkan kesiapan peserta didik dan tujuan pendidikan nasional. Kurikulum 2013 menjadi alat penyelenggara pendidikan pertama kali pada tahun 2013/2014. Sebagai konsep kurikulum baru, kurikulum ini tidak dapat diterapkan secara universal dan cepat, sehingga masih sedikit sekolah yang menerapkan kurikulum 2013.
Dengan adanya kurikulum proses belajar dan pembelajaran akan berjalan secara terstruktur dan tersistem demi mencapai tujuan pembelajaran yang diinginkan. Pengembangan kurikulum menjadi sangat penting sejalan dengan kemajuan ilmu pengetahuan, teknologi, seni budaya, dan perubahan pada masyarakat.

Kurikulum 2013 merupakan penyempurnaan dari Kurikulum Tingkat Satuan Pendidikan (KTSP). Kurikulum 2013 pada dasarnya adalah perubahan pola pikir dan budaya mengajar dari kemampuan mengajar tenaga pendidik dalam melaksanakan proses belajar mengajar. Dalam pelaksanaan kurikulum 2013 ini peranan guru sangat penting selaku aktor dalam proses pembelajaran, baik buruknya 
keterlaksanaan kurikulum dapat dipengaruhi oleh guru dalam mengimplementasikannya.

Permendikbud No. 69 tahun 2013, menyatakan bahwa kurikulum 2013 bertujuan untuk mempersiapkan manusia Indonesia agar memiliki kemampuan hidup sebagai pribadi dan warga negara yang beriman, produktif, kreatif, inovatif, dan afektif serta mampu berkontribusi pada kehidupan bermasyarakat, berbangsa, bernegara, dan peradaban dunia. Hal ini dimaksudkan agar pengetahuan peserta didik di Indonesia dalam mempelajari suatu materi dapat tersusun secara utuh dari berbagai sisi disiplin ilmu.

Proses pembelajaran sepenuhnya diarahkan pada pengembangan ketiga ranah (kognitif, afektif, psikomotor) tersebut secara utuh, penilaian pembelajaran berdasarkan kurikulum 2013 memakai berbagai macam teknik penilaian dalam setiap aspek, guru yang belum menguasai teknik penilaian akan mengalami kesulitan penerapan penilaian memakai instrumen kurikulum 2013.

Dalam perencanaan proses pembelajaran ini ada beberapa aspek yang perlu diperhatikan yaitu: desain pembelajaran, rencana pelaksanaan pembelajaran, pelaksanaan pembelajaran, dan penilaian hasil dan proses pembelajaran. Kurikulum disusun dengan maksud menjadi acuan dan pegangan lembaga pendidikan dalam merencanakan, mempersiapkan dan melaksanakan program-programnya.

Acuan dan prinsip penyusunan kurikulum 2013 mengacu pada pasal 36 Undang-Undang No. 20 tahun 2003, yang menyatakan bahwa penyusunan kurikulum harus memperhatikan peningkatan iman dan takwa; peningkatan akhlak mulia; peningkatan potensi, kecerdasan, dan minat peserta didik; keragaman potensi daerah dan lingkungan; tuntutan pembangunan daerah dan nasional; tuntutan dunia kerja; perkembangan ilmu pengetahuan, teknologi, dan seni; agama; dinamika perkembangan global; dan persatuan nasional dan nilai-nilai kebangsaan.

Penerapan kurikulum 2013 menimbulkan kendala yang dihadapi oleh sekolah, guru dan peserta didik. Penambahan jam pelajaran per-minggu akan menyulitkan pihak sekolah dalam pengembangan kurikulum. Pada sekolahsekolah swasta, kurikulum baru jelas menimbulkan beban baru bagi yayasan. Karena harus memfasilitasi peningkatan kualitas guru lewat pelatihan, pengadaan perpustakaan yang lengkap, dan pendidikan tambahan agar guru dapat mengimplementasikan kurikulum 2013 dengan baik, dengan biaya yang di tanggung sendiri pihak yayasan. Pemilihan minat dan jurusan yang dimulai peserta didik sejak kelas $\mathrm{X}$ membuat bingung peserta didik baru karena mereka langsung dihadapkan dengan program IPA atau IPS.

\section{PEMBAHASAN}

\section{Kurikulum 2013}

Kurikulum 2013 adalah kurikulum terbaru yang diluncurkan oleh Departemen Pendidikan Nasional pada tahun 2013 sebagai bentuk pengembangan dari kurikulum sebelumnya yaitu kurikulum 2006 atau Kurikulum Tingkat Satuan Pendidikan yang mencangkup kompetensi sikap, pengetahuan, dan keterampilan secara terpadu. Hal ini senada dengan apa yag ditegaskan dalam pasal 1 ayat 29 Undang-Undang no. 20 tahun 2003 bahwa kurikulum merupakan pengaturan mengenai tujuan, isi, dan bahan pelajaran serta cara yang digunakan sebagai pedoman 
penyelenggara kegiatan pembelajaran untuk mencapai tujuan pendidikan tertentu.

Pengertian kurikulum menurut ahli:

1. Dr. H. Nana Sudjana Tahun (2005). Kurikulum merupakan niat dan harapan yang dituangkan kedalam bentuk rencana maupun program pendidikan yang dilaksanakan oleh para pendidik di sekolah. Kurikulum sebagai niat dan rencana, sedangkan pelaksaannya adalah proses belajar mengajar. Yang terlibat didalam proses tersebut yaitu pendidik dan peserta didik.

2. Prof. Drs. H. Darkir, menyatakan bahwa kurikulum merupakan alat dalam mencapai tujuan pendidikan. Jadi, kurikulum ialah program pendidikan dan bukan program pengajaran, sehingga program itu direncanakan dan dirancang sebagai bahan ajar dan juga pengalaman belajar.

3. Kerr, J.F (1968). Kurikulum merupakan seluruh pembelajaran yang dirancang dan dilakukakan secara individu maupun kelompok, baik didalam sekolah maupun diluar sekolah.

4. Inlow (1966). Kurikulum merupakan suatu usaha menyeluruh yang dirancang secara khusus guna untuk membimbing peserta didik dalam memperoleh hasil belajar dari pembelajaran yang sudah ditetapkan.

5. Daniel Tanner dan Laurel Tanner. Mereka mengemukakan pengertian kurikulum sebagai suatu pengalaman pembelajaran yang terarah, terencana secara sistematis juga tersusun melalui proses rekonstruksi pengetahuan dan pengalaman serta berada dibawah pengawasan lembaga pendidikan sehingga para peserta didik memiliki motivasi dan minat belajar yang tinggi.

Dari uraian di atas dapat disimpulkan bahwa kurikulum adalah seperangkat rencana mengenai tujuan isi dan bahan pelajaran yang disusun secara terstruktur untuk suatu bidang studi yang perlu dipelajari untuk menentukan tingkat pencapaian kemampuan peserta didik dalam mengembangkan potensi dirinya.

Menurut Wina Sanjaya (2013:46) menyatakan bahwa sistem kurikulum terbentuk oleh empat komponen yaitu: komponen tujuan, isi kurikulum, metode atau pencapaian tujuan, komponen evaluasi, dan setiap komponen harus berkaitan satu sama lain.

1. Komponen Tujuan

Menurut Wina Sanjaya dan Dian Andayani (2013:46) menyatakan bahwa komponen tujuan kurikulum berhubungan dengan arah atau hasil yang diharapkan. Dalam skala makro, tujuan kurikulum berkaitan dengan filsafat atau nilai yang dianut masyarakat. Sedangkan dalam skala mikro, tujuan kurikulum berhubungan dengan visi dan misi sekolah serta tujuantujuan yang lebih sempit, seperti tujuan mata pelajaran dan tujuan proses pembelajaran.

2. Komponen Isi/Materi Pembelajaran

Isi kurikulum merupakan komponen yang berhubungan dengan pengalaman belajar yang harus dimiliki siswa. Isi kurikulum itu menyangkut semua aspek baik yang berhubungan dengan pengetahuan atau materi pelajaran yang biasanya tergambarkan pada isi setiap mata pelajaran yang diberikan maupun aktifitas itu seluruhnya diarahkan untuk mencapai tujuan yang ditentukan

3. Komponen Metode/Pencapaian Tujuan

Metode merupakan komponen yang memilki peran yang sangat penting sebab berhubungan dengan implementasi kurikulum. Metode meliputi rencana, strategi dan perangkat kegiatan yang 
direncanakan untuk mencapai tujuan tertentu secara optimal.

\section{Komponen Evaluasi}

Melalui evaluasi dapat ditentukan nilai dan arti kurikulum, sehingga dapat dijadikan bahan pertimbangan apakah suatu kurikulum perlu dipertahankan atu tidak, dan bagian mana yang harus disempurnakan. Evaluasi merupakan komponen untuk melihat efektivitas pencapaian tujuan.

Kurikulum sebagaimana yang ditegaskan dalam Pasal 1 Ayat (19) UU Nomor 20 Tahun 2003 adalah seperangkat rencana dan pengaturan mengenai tujuan, isi, dan bahan pelajaran serta cara yang digunakan sebagai pedoman penyelenggaraan kegiatan pembelajaran untuk mencapai tujuan pendidikan tertentu.

Kurikulum 2013 merupakan kurikulum baru yang mulai diterapkan pada tahun pelajaran 2013/2014. Dengan demikian, dapat dipahami bahwa kurikulum 2013 adalah sebuah kurikulum yang dikembangkan untuk meningkatkan dan menyeimbangkan kemampuan soft skills dan hard skill yang berupa sikap, keterampilan, dan pengetahuan.

Dalam konteks ini kurikulum 2013 berusaha untuk lebih menanamkan nilainilai yang tercermin pada sikap dapat berbanding lurus dengan keterampilan yang diperoleh peserta didik melalui pengetahuan dibangku sekolah. Dengan kata lain soft skill dan hard skill dapat tertanam secara seimbang, berdampingan, dan mampu diaplikasikan dalam kehidupan sehari-hari. Dengan adanya kurikulum 2013 harapan peserta didik dapat memiliki kompetensi sikap, keterampilan, pengetahuan yang meningkat dan berkembang sesuai dengan jenjang pendidikan yang telah ditempunya sehingga akan dapat berpengaruh dan menentukan kesuksesan dalam kehidupan selanjutnya.

Kurikulum 2013 dikembangkan berdasarkan faktor-faktor sebagai berikut:

a. Tantangan Internal, antara lain terkait dengan kondisi pendidikan dikaitkan dengan tuntutan pendidikan yang mengacu kepada 8 (delapan) Standar Nasional Pendidikan yang meliputi standar isi, standar proses, standar kompetensi lulusan, standar pendidik dan tenaga kependidikan, standar sarana dan prasarana, standar pengelolaan, standar pembiayaan, dan standar penilaian pendidikan.

b. Tantangan Eksternal, antara lain terkait dengan arus globalisasi dan berbagai isu yang terkait dengan masalah lingkungan hidup, kemajuan teknologi dan informasi, kebangkitan industri kreatif dan budaya, dan perkembangan pendidikan di tingkat internasional. Arus globalisasi akan menggeser pola hidup masyarakat dari agraris dan perniagaan tradisional menjadi masyarakat industri dan perdagangan modern. Tantangan eksternal juga terkait dengan pergeseran kekuatan ekonomi dunia, pengaruh dan imbas teknosains serta mutu, investasi, dan transformasi bidang pendidikan.

\section{Perencanaan Pembelajaran Kurikulum 2013}

Secara terminologi rencana pembelajaran terbagi menjadi dua kata yaitu perencanaan dan pembelajaran. Perencanaan berasal dari kata rencana yaitu pengambilan keputusan untuk mencapai suatu tujuan tertentu. Dengan demikian proses perencanaan harus dimulai dengan penetapan tujuan yang hendak dicapai, analisis kebutuhan serta dokumen yang lengkap, kemudian menetapkan langkah- 
langkah untuk mencapai tujuan secara efektif dan efesien.

Terdapat empat unsur perencanaan minimal yang harus dimiliki:

1. Adanya tujuan yang harus dicapai. Tujuan merupakan arah yang harus dicapai. Disusun secara jelas dan sistematis.

2. Adanya strategi yang digunakan untuk mencapai tujuan yang diingingkan. Strategi berkaitan dengan penetapan keputusan yang diambil. Misalnya keputusan tentang waktu pelaksanaan, jumlah waktu, pembagian setiap tugas dan wewenan, langkah-langkah yang harus dikerjakan serta penetapan kriteria keberhasilan.

3. Terdapat sumber daya yang dapat mendukung. Sumber daya yang dapat mendukung, didalamnya meliputi penetapan sarana dan prasarana, anggaran biaya, dan sumber daya lainnya seperti pemanfaatan waktu yang dibutuhkan untuk mencapai tujuan yang telah dirumuskan sebelumnya.

4. Implementasi setiap keputusan yang diambil. Implementasi adalah pelaksanaan dari strategi dan penetapan sumber daya. Artinya sebuah tujuan akan berarti apabila diterapkan atau dilakukan di dunia nyata.

Pembelajaran dapat diartikan sebagai proses kerja sama antara guru dan siswa dalam memanfaatkan segala potensi dan sumber yang ada baik potensi yang bersumber dalan diri seperti minat, bakat dan kemampuan dasar termaksud gaya belajar maupun potensi diluar diri seperti lingkungan, sarana dan sumber belajar.

Perencanaan pembelajaran yang terkait dengan bahan atau isi pembelajaran berfungsi untuk mengukur seberapa jauh tujuan itu telah tercapai dan tindakan apa yang harus dilakukan apabila tujuan belum tercapai. Dalam hal ini memusatkan pembahasan kepada cara menyusun perencanaan atau persiapan mengajar yang lebih dikenal dengan Rencana Pelaksanaan Pembelajaran (RPP).

\section{Implementasi Rencana Pelaksanaan Pembelajaran Kurikulum 2013}

Usman (2002:70) dalam bukunya, Konteks Implementasi Berbasis Kurikulum mengemukakan bahwa implementasi adalah bermuara pada aktivitas, aksi, tindakan, atau adanya mekanisme suatu sistem. Implementasi bukan sekedar aktivitas, tetapi suatu kegiatan yang terencana dan untuk mencapai tujuan kegiatan.

Kurikulum $2013 \quad$ yang implementasinya dilakukan secara serentak tahun 2014 pada seluruh sekolah dilinkungan pendidikan dasar dan menengah, memosisikan guru tetap memegang perang penting terutama dalam merealisasikan pembelajaran. Kendati demikian dalam kurikulum baru ini terjadi pengurangan peran dan fungsi guru, sekaligus mengurangi beban kerjanya, khususnya pekerjaan-pekarjaan yang sifatnya administratif.

Implementasi kurikulum 2013 yang berbaris kararkter dan kompetensi, memerankan guru sebagai pembentuk karakter dan kompetensi peserta didik, yang harus kreatif dalam memilih dan memilah, serta mengembangkan metode dan materi pelajaran. Guru harus profesional dalam membentuk karakter dan kompetensi peserta didik sesuai dengan karakteristik individual masing-masing dan harus tampil menyenangkan dihadapan peserta didik dalam kondisi dan suasana bagaimanapun.

Peraturan Menteri Pendidikan dan Kebudayaan Nomor 65 Tahun 2013 tentang Standar Proses Pendidikan Dasar dan Menengah menuliskan bahwa, "sesuai 
dengan Standar Kompetensi Lulusan, sasaran pembelajaran mencakup pengembangan ranah sikap, pengetahuan, dan keterampilan yang dielaborasi untuk setiap satuan pendidikan." Ketiga ranah kompetensi tersebut memiliki lintasan perolehan (proses psikologis) yang berbeda.

Karaktersitik kompetensi beserta perbedaan lintasan perolehan turut serta mempengaruhi karakteristik standar proses. Untuk memperkuat pendekatan ilmiah (scientific), tematik terpadu (tematik antarmata pelajaran), dan tematik (dalam suatu mata pelajaran) perlu diterapkan pembelajaran berbasis penyingkapan/ penelitian (discovery/inquiry learning). Untuk mendorong kemampuan peserta didik untuk menghasilkan karya kontekstual, baik individual maupun kelompok maka sangat disarankan menggunakan pendekatan pembelajaran yang menghasilkan karya berbasis pemecahan masalah (project based learning). Rincian gradasi sikap, pengetahuan, dan keterampilan.

Pardomuan Nauli Josip Mario Sinambela (2013) menulis "Kurikulum 2013 dan implementasinya dalam Pembelajaran." Hasil penelitian menunjukkan bahwa K-13 menuntut agar dalam pelaksanaan pembelajaran siswa diberi kebebasan berpikir memahami masalah, membangun strategi penyelesaian masalah, mengajukan ide-ide secara bebas dan terbuka. Kegiatan guru dalam pembelajaran adalah melatih dan membimbing siswa berpikir kritis dan kreatif dalam menyelesaikan masalah.

Guru harus berupaya untuk mengorganisasikan kerjasama dalam kelompok belajar, melatih siswa berkomunikasi menggunakan grafik, diagram, skema, dan variabel. Diharapkan seluruh hasil kerja selalu dipresentasikan di depan kelas untuk menemukan berbagai konsep, hasil penyelesaian masalah, aturan serta prinsip yang ditemukan melalui proses pembelajaran. Pembelajaran tidak hanya ditekankan pada satu aspek saja tetapi keseimbangan pada aspek afektif, aspek psikomotorik, dan aspek kognitif.

Tabel 1. Rincian Gradasi Sikap, Pengetahuan, dan Keterampilan

\begin{tabular}{|l|l|l|}
\hline Sikap & Pengetahuan & Keterampilan \\
\hline Menerima & Mengingat & Mengamati \\
Menjalankan & Menghayati & Menanya \\
Menghargai & Menerapkan & Mencoba \\
Menghayati & Menganalisis & Menalar \\
Mengamalkan & Mengevaluasi & Menyajikan \\
\hline
\end{tabular}

Mengacu pada ketiga kompetensi tersebut, dalam pelaksanaan pembelajaran pun harus disetting sedemikian rupa sehingga apa yang menjadi tujuan utama pembelajaran dapat tercapai. Berkenaan dengan hal ini ada beberapa prinsip yang harus diperhatikan bersama 0leh para guru dalam melaksanakan pembelajaran diantaranya: (1) berpusat pada peserta didik, (2), mengembangkan kreatifitas peserta didik; (3), menciptakan kondisi menyenangkan dan menantang; bermuatan nilai, etika, dan kinestetika; (5) menyediakan pengalam belajar yang beragam melalui penerapan berbagai strategi dan metode pembelajaran yang menyenangkan, kontekstual efektif, efisien dan bermakna.

Berlangsungnya proses pembelajaran tidak terlepas dari komponenkomponen yang ada di dalamnya, komponen-komponen proses pembelajaran adalah "peserta didik, guru, tujuan pembelajaran, materi/isi, metode, media, dan evaluasi."

\section{Mengimplementasikan Kurikulum 2013}

Pada penerapan (implementasi Kurikulum 2013) di lapangan (baca: 
sekolah), guru salah satunya harus menggunakan pendekatan ilmiah (scientific), karena pendekatan ini lebih efektif hasilnya dibandingkan pendekatan tradisional.

\section{Kriteria Pendekatan Scientific (Ilmiah)}

Lalu bagaimanakah kriteria sebuah pendekatan pembelajaran sehingga dapat dikatakan sebagai pendekatan ilmiah atau pendekatan scientific? Berikut ini tujuah (7) kriteria sebuah pendekatan pembelajaran dapat dikatakan sebagai pembelajaran scientific, yaitu:

1) Materi pembelajaran berbasis pada fakta atau fenomena yang dapat dijelaskan dengan logika atau penalaran tertentu; bukan sebatas kira-kira, khayalan, legenda, atau dongeng semata.

2) Penjelasan guru, respon siswa, dan interaksi edukatif guru-siswa terbebas dari prasangka yang serta-merta, pemikiran subjektif, atau penalaran yang menyimpang dari alur berpikir logis.

3) Mendorong dan menginspirasi siswa berpikir secara kritis, analistis, dan tepat dalam mengidentifikasi, memahami, memecahkan masalah, dan mengaplikasikan materi pembelajaran.

4) Mendorong dan menginspirasi siswa mampu berpikir hipotetik dalam melihat perbedaan, kesamaan, dan tautan satu sama lain dari materi pembelajaran.

5) Mendorong dan menginspirasi siswa mampu memahami, menerapkan, dan mengembangkan pola berpikir yang rasional dan objektif dalam merespon materi pembelajaran.

6) Berbasis pada konsep, teori, dan fakta empiris yang dapat dipertanggungjawabkan.

7) Tujuan pembelajaran dirumuskan secara sederhana dan jelas, namun menarik sistem penyajiannya.
Selanjutnya, langkah-langkah pembelajaran pada pendekatan scientific (pendekatan ilmiah) dijelaskan pada gambar berikut.

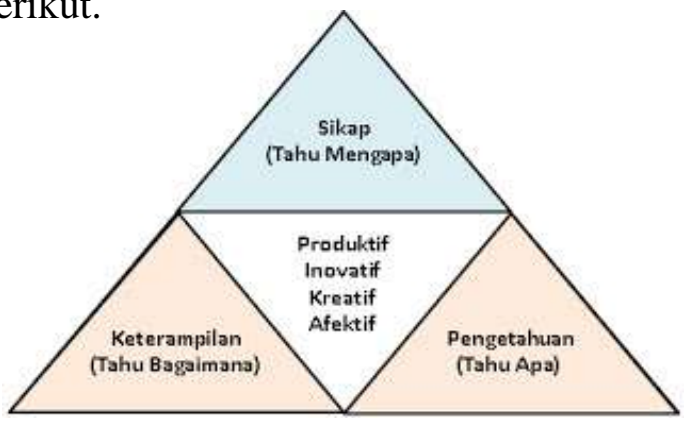

Proses pembelajaran yanag mengimplementasikan pendekatan scientific akan menyentuh tiga ranah, yaitu: sikap (afektif), pengetahuan (kognitif), dan keterampilan (psikomotor). Dengan proses pembelajaran yang demikian maka diharapkan hasil belajar melahirkan peserta didik yang produktif, kreatif, inovatif, dan afektif melalui penguatan sikap, keterampilan, dan pengetahuan yang terintegrasi. Perhatikan diagram berikut. Adapun penjelasan dari diagram pendekatan pembelajaran scientific (pendekatan ilmiah) dengan menyentuh ketiga ranah tersebut dapat dijelaskan sebagai berikut:

a. Ranah sikap menggamit transformasi substansi atau materi ajar agar peserta didik "tahu mengapa."

b. Ranah keterampilan menggamit transformasi substansi atau materi ajar agar peserta didik "tahu bagaimana".

c. Ranah pengetahuan menggamit transformasi substansi atau materi ajar agar peserta didik "tahu apa."

d. Hasil akhirnya adalah peningkatan dan keseimbangan antara kemampuan untuk menjadi manusia yang baik (soft skills) dan manusia yang memiliki kecakapan dan pengetahuan untuk hidup secara layak (hard skills) dari peserta didik yang meliputi aspek kompetensi sikap, pengetahuan, dan keterampilan. 
e. Kurikulum 2013 menekankan pada dimensi pedagogik modern dalam pembelajaran, yaitu menggunakan pendekatan ilmiah.

f. Pendekatan ilmiah (scientific appoach) dalam pembelajaran sebagaimana dimaksud meliputi mengamati, menanya, menalar, mencoba, membentuk jejaring untuk semua mata pelajaran.

Adapun langkah-langkah pembelajaran scientific meliputi:

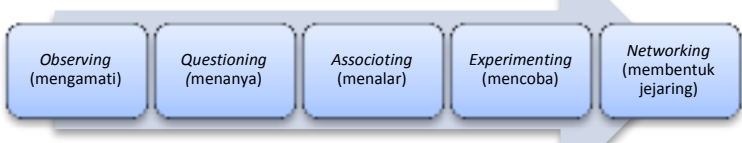

\section{Mengevaluasi Pembelajaran pada Kurikulum 2013}

Secara harfiah, kata evaluasi berasal dari bahasa Inggris evaluation; dalam bahasaArab: al-Taqdir; dalam bahasa Indonesia berarti: penilaian. Akar katanya adalah value; dalam bahasa Arab: alQimah; dalam bahasa Indonesia berarti; nilai. Dengan demikian secara hafiah, evaluasi pendidikan dapat diartikan sebagai: penilaian dalam (bidang) pendidikan atau penilaian mengenai hal-hal yang berkaitan dengan kegiatan pendidikan. Dari segi istilah, evaluasi pendidikan adalah kegiatan atau proses penentuan nilai pendidikan, sehingga dapat diketahui mutu/hasilnya.

$$
\text { Prinsip-prinsip yang harus }
$$
diperhatikan oleh guru pada saat melaksanakan penilaian untuk implementasi kurikulum 2013 sebagai berikut:

a. Sahih adalah penilaian yang didasarkan pada data yang memang mencermingkan kemampuan yang ingin diukur.

b. Objektif adalah penilaian yang didasarkan pada prosedur dan kriteria yang jelas dan tidak boleh dipengaruhi oleh subjektivitas penilai (guru).

c. Adil adalah suatu penilaian yang tidak menguntungkan atau merugikan siswa hanya karena mereka (bisa jadi) kebutuhan khusus serta memiliki perbedaan latar belakang agama, budaya, adat istidat, status sosial, ekonomi, dan gender.

d. Terpadu adalah penilaian dikatakan memenuhi prinsip apabila guru yang merupakan salah satu komponen yang tidak terpisahkan dalam pembelajaran.

e. Transparan A, adalah dimana kriteria penilaian dan dasar pengambilan keputusan yang digunakan diketahui oleh semua pihak yang berkepentingan.

f. Menyeluruh dan berkesinambungan adalah mencakup segala aspek kompetensi dengan menggunakan berbagai teknik yang sesuai. Dengan demikian akan dapat memantau perkembangan kemampuan siswa.

g. Sistematis adalah penialaian yang dilakukan oleh guru harus terencana dan dilakukan secara bertahap dengan mengikuti langkah-langkah yang baku.

h. Akuntabel adalah penialaian yang proses dan hasilnya dapat dipertanggungjawabkan baik dari segi teknik, prosedur maupun hasilnya.

i. Edukatif adalah penilaian dilakukan untuk kepentingan dan kemajuan pendidikan siswa.

Ada tiga istilah yang sering digunakan dalam evaluasi, yaitu tes, pengukuran, dan penilaian.

1. Tes merupakan salah satu cara menaksir besarnya kemampuan seseorang secara tidak langsung, yaitu melalui respons seseorang terhdap stimulus atau pertanyaan.Pengukuran dinyatakan sebagai proses penetapan angka 
terhadap individu atau karakteristinya menurut aturan tertentu.

2. Pengukuran adalah suatu proses atau kegiatan untuk menentukan kuantitas sesuatu. Kata "sesuatu" bisa berarti peserta didik, guru, gedung sekolah, meja belajar, white board, dan sebagainya.

3. Assessment atau penilaian sebagai kegiatan mengumpulkan data hasil pengukuran berdasarkan kriteria dan aturan-aturan yang sudah ditentukan sehingga menjadi sebuah kesimpulan akhir atau bisa juga dikatakan penilaian adalah sebuah jalan untuk mentafsirkan data yang sudah ditemukan.

Penilaian pendidikan sebagai proses pengumpulan dan pengolahan informasi untuk mengukur pencapaian hasil belajar peserta didik mencakup penilaian otentik, penilaian diri, penilaian berbasis portofolio, ulangan, ulangan harian, ulangan tengah semester, dan ulangan akhir semester yang diuraikan sebagai berikut.

1. Penilaian otentik merupakan penilaian yang dilakukan secara komprehensif untuk menilai aspek sikap, pengetahuan, keterampilan mulai dari masukan (input), proses, sampai keluaran (output) pembelajaran. Penilaian otentik bersifat alami, apa adanya, tidak dalam suasana tertekan.

2. Penilaian diri merupakan penilaian yang dilakukan sendiri oleh peserta didik secara reflektif untuk membandingkan posisi relatifnya dengan kriteria yang telah ditetapkan.

3. Penilaian berbasis portofolio merupakan penilaian yang dilaksanakan untuk menilai keseluruhan entitas proses belajar peserta didik termasuk penugasan perseorangan dan/atau kelompok di dalam dan/atau di luar kelas dalam kurung waktu tertentu.
4. Ulangan merupakan proses yang dilakukan untuk mengukur pencapaian kompetensi peserta didik secara berkelanjutan dalam proses pembelajaran, untuk memantau kemajuan dan perbaikan hasil belajar peserta didik.

5. Ulangan harian merupakan kegiatan yang dilakukan secara periodik untuk menilai kompetensi peserta didik setelah menyelesaikan satu sub-tema. Ulangan harian terintegrasi dengan proses pembelajaran lebih untuk mengukur aspek pengetahuan, dalam bentuk tes tulis, tes lisan, dan penugasan.

6. Ulangan tengah semester merupakan kegiatan yang dilakukan oleh pendidik untuk mengukur pencapaian kompetensi peserta didik setelah melaksanakan 8-9 minggu kegiatan pembelajaran.

7. Ulangan akhir semester merupakan kegiatan yang dilakukan oleh pendidik untuk mengukur pencapaian kompetensi peserta didik di akhir semester.

Selain penilaian di atas, ada beberapa jenis penilaian antara lain: (1) Ujian Tingkat Kompetensi (UTK) merupakan kegiatan pengukuran yang dilakukan oleh satuan pendidikan untuk mengetahui pencapaian tingkat kompetensi. Cakupan UTK meliputi sejumlah kompetensi dasar yang merepresentasikan Kompetensi Inti pada tingkat kompetensi tersebut; dan (2) Ujian Mutu Tingkat Kompetensi (UMTK) merupakan kegiatan pengukuran yang dilakukan oleh pemerintah untuk mengetahui pencapaian tingkat kompetensi. Cakupan UMTK meliputi sejumlah Kompetensi Dasar yang merepresentasikan Kompetensi Inti pada tingkat kompetensi tersebut. 


\section{KESIMPULAN}

Kurikulum 2013 adalah bentuk pengembangan dari kurikulum sebelumnya yaitu kurikulum KTSP, yang implementasinya dimulai pada Tahun 2013. Kurikulum 2013 ini lebih menekankan kepada kompetensi dan karakter pada peserta didik. Dimana tujuannya untuk menjadikan manusia yang mampu menghadapi tantangan zaman, manusia terdidik yang beriman dan bertaqwa kepada Allah Yang Maha Esa, berakhlak mulia, sehat, berilmu, cakap, kreatif, mandiri, dan menjadi warga Negara yang demokratis dan bertanggung jawab. Dengan demikian untuk mewujudkan itu semua maka guru dituntut untuk secara profesional merancang Strategi pembelajaran afektif dan bermakna, mengorganisasikan pembelajaran, memilih pendekatan pembelajaran yang tepat, menentukan prosedur pembelajaran dan pembentukan kompetensi secara efektif, serta menetapkan kriteria keberhasilan. kurikulum pendidikan memberikan ruang dan pemahaman kepada pembelajar dalam menciptakan konsepnya sendiri sebagai bagian dari dunia.

\section{DAFTAR PUSTAKA}

Arief, Muhammad Miftah. 2015. Konsep Dasar dalam Evaluasi Kurikulum 2013. (Online, https://artikelmiftaharief.blogspot.com/2017/04/konsep-dasar-evaluasi-dalam-kurikulum. html, Diakses 23 Desember 2018).

Baiq Emilia, Susdiana Nurachman Hanafi \& Sudirman. 2018. Implementasi Kurikulum 2013 Pada Pembelajaran Bahasa Indonesia di SMA Lombok Tengah. Lingua, 15(2), 208-210.

Kumpulan Makalah. 2018. Evaluasi dan Penilaian Dalam Kurikulum 2013. (Online, Alifyz. blogspot.com/2018/01/evaluasi-dan-penilaian-dalam-kurikulum-2013.htm1, Diakses 23 Desember 2018).

Kurinasih, Imas \& Berlin Sani. 2014. Sukses Mengimplementasikan Kurikulum 2013: Memahami Berbagai Aspek dalam Kurikulum 2013. Surabaya: Kata Pena.

Kurniaman, Otang \& Noviana, Eddy. 2017. Penerapan Kurikulum 2013 dalam Meningkatkan Keterampilan, Sikap, dan Pengetahuan. Jurnal Primary, 6(1), 390.

Mansyur, Umar. 2013. Evaluasi Kompetensi Pedagogik Guru Bahasa Indonesia SMP Peserta MGMP dan yang Bukan Peserta MGMP di Kabupaten Pinrang. Thesis. Makassar: Universitas Negeri Makassar.

Mansyur, Umar. 2018. Sistem Pendidikan Nasional: Mencerdaskan atau Menindas? https://doi.org/10.31227/osf.io/kfvb5

Mulyasa. 2013. Pengembangan dan Implementasi Kurikulum 2013. Bandung: PT. Remaja Rosdakarya.

Musfiqon, Nurdyansyah. 2015. Pendekatan Pembelajaran Saintifik. Sidoarjo: Nizamia Learning Center.

Sitti Hardianti. 2017. Implementasi Kurikulum 2013 pada Proses Pembelajaran oleh Guru Mata Pelajaran Fisika Tingkat SMAN Kabupaten Bone. Skripsi. Makassar: Univeritas Islam Negeri Alaudin. 